\title{
REGIONAL SHORT STORIES IN TRANSLATION FOR DEVELOPING LANGUAGE SKILLS OF EFL LEARNERS: A SELECTED PART OF SOWRIS' TELUGU SHORT STORY 'REMINISCENCE'
}

\author{
Dr. S.D.Sasi Kiran, \\ Associate Professor of English, \\ Department of Sciences \& Humanities, Vignan \\ University, \\ Vadlamudi, Guntur-522213, Andhra Pradesh
}

\begin{abstract}
Regional short stories in translation have been the focal point for centuries for diverse Indian faculty of English for diverse reasons, essentially after realising outstanding teaching components embedded in regional short stories (here Telugu) in translation, having been important topics of debate and discussion for developing language skills of EFL learners by scores of ELT professional practitioners. The short stories in translation, however, put forward valid, resourceful and unscathed material in language selection on one hand, and mirthful and motivational as well on the other hand. A highly effective approach for teaching and learning of foreign language like English, short stories in translation from regional into English may be recommended on similar grounds by ELT professional intellectuals. In this background, the present paper investigates the use of short stories in translation for developing reading comprehension skill and the researcher's perspective on use of short stories in translation in EFL context that forms an essential element of the discussion in the paper. A selected part of Telugu short story 'Reminiscence' by Sowris, a popular Telugu female writer, is used here for augmenting an in depth discussion.
\end{abstract}

Keywords: Short stories in translation, Indian faculty of English, language selection, developing reading comprehension skill

\section{Introduction}

Among literary genres, short stories in translation seem to be the most suitable choice for this to facilitate students improve the four skills-listening, speaking, reading and writing-more effectively because of the motivational benefit embedded in the stories. The purpose of this paper is to familiarize EFL instructors with the effectiveness of using short stories in Translation in EFL instruction.

Regional short stories in translation have been the focal point for centuries for diverse Indian faculty of English for diverse reasons, essentially after realising outstanding teaching components embedded in regional short stories (here Telugu) in translation, having been important topics of debate and discussion for developing language skills of EFL learners by scores of ELT professional practitioners. The short stories in translation, however, put forward valid, resourceful and unscathed material in language selection on one hand, and mirthful and motivational as well on the other hand. A highly effective approach for teaching and learning of foreign language like English, short stories in translation from regional into English may be recommended on similar grounds by ELT professional 
intellectuals. A lot of students do a translation exercise with fun. If I remember correctly, I used to do the same in high school. This excerpt I had translated looks reasonably agreeable. Firstly, I created one for my own students, which I'd share it here.

\section{Literature Review}

There is a vast plethora of literature available across the various languages spoken in India. The role of translators and their understanding, discussion, analysis, and craft-in a multilingual scenario becomes more vital and deserves urgent recognition. Students are to be exposed to the importance of translation and also to the various questions in the process: How do students draw near to and study complexities of linguistic shift in literary and non-literary texts? How much of evolution of translation should they be acquainted with? How much theory should they learn of Indian translation? Do they engage in pleasure of creating their own translations and discussing those by others? Is it alright to design and encourage interactivity in the classroom? M. K. C. Uwajeh emphasizes the usefulness of translational activity as a tool for linguistic insight into the workings of source languages and the potential for translation at the same time. The ongoing debate about the role of teaching translation and interpreting in the present times has been reaching out all language professionals. Short stories are the most appropriate literary genre to employ in English teaching due to its conciseness, is supported by Collie and Slater (1991: 196) when they list four advantages of using short stories for language teachers. First, short stories are practical as their length is long enough to cover entirely in one or two class sessions. Second, short stories are not complicated for students to work with on their own. Third, short stories have a variety of choice for different interests and tastes. Finally, short stories can be used with all levels (beginner to advance), all ages (young learners to adults) and all classes. The same is applicable to short stories in translation too.

Materials: A selected part of Translated Telugu short story by Sowris 'Reminiscence', a popular Telugu female writer

"How nice is the sun shine!

How green the trees look today!

I have never seen such greenness

before. How is that? Never have

I seen earlier either trees or flowers so beautiful?

Why is it so

The cool breeze is causing horripulation all over my body. Why do I enjoy the breeze so much instead of closing the doors and covering myself with a pile of rugs?

Why there is so much of joy in watching the trees, the breeze and the sunshine? Is it because of healthy recovery after all these bed-ridden days at the hospital? The nurse suggested that I should have a stroll in the garden for a short while to get better.

Just better? No, it's not just that. There is already a feeling of full recovery. 
ELK

Asia Pacific Journals

How colourful are these flowers!

Dazzling to the eyes as they are.

Flowers! And flowers!

How many days have passed - How

many?

Before being at the hospital, where was I?

Wasn't I roaming amid the flowers and trees?

Where was I? Yes, where was I?"

\section{Method}

I distributed the same excerpt in original to all my student teams of six members. They were asked to read out 'silent once and aloud again'. Certain expressions and words were discussed at length. This translation exercise examines one of my favorite parts of the selected story. I took all translations done by my student teams. They did an instant translation. I found all of these translations reasonably good. Translated sheets were then inter exchanged among teams. The given translation is simple on vocabulary grounds but complex on syntax grounds. Students feel it easy while reading and feel it difficult while translating.

\section{Analysis - session}

After examining the translations, students will answer the questions follow.

1. Compare the translations. What are the major differences that you see? The major similarities?
ELK Asia Pacific Journals - Special Issue

ISBN: 978-81-930411-1-6

2. Compare closely your version with atleast one and write on what you feel.

3. Which translation do you think is most interesting/exciting/easy to understand/appealing?

4. Which don't appear to be easy for translation work

5. How do you think a prose translation differs from a poetic one? What qualities might be compromised in a prose translation?

6. What conclusions can you draw about the process of translation?

7. What would your advice be to translators (consider the following: What do they need to think about in order to produce a readable translation that is still faithful to the spirit of the text? What should they avoid doing?)

\section{Activity Session}

This discussion would encourage students to think in English through the process of reading Telugu selections and then composing in English, and the process of translating into English offers a number of highly structured composition exercises that introduce students to a deeper understanding of grammar and prose as well as to greater facility in reading and understanding an English text. Exercises may be given as pre/post translation.

\section{Exercise 1 (Base Activity)}

Translate the text into English. (Given an original selected passage in Telugu) Here I 
ELK

Asia Pacific Journals

have given an excerpt of Sowris short story in translation, 'Reminiscence' and the passage in translation serves to be a model after students do their translation work.

\section{Exercise 2}

Now find synonyms for the following words in italics taken from the passage above breeze, horripilation, stroll, roaming, amid

\section{Exercise 3}

Now find words which mean the opposite of the above words

\section{Exercise 4}

How would you translate the following lines into English? Exact meaning of words is given.

Nenu/akkadaki/vellanu

$\checkmark \quad$ I/there/went

Athanu/evaru?

$\checkmark \quad \mathrm{He} / \mathrm{who}$ ?

Nenu/ ekkada/ vunnanu?

$\checkmark \quad$ I/where/ stay

\section{Exercise 4}

Design and offer a Level 1 course as a minor (Fill the sub sectioned requirements in bold in a template)

Prerequisites: Competence in any language other than English or permission of the instructor.

Name of the course: Translation for Beginners

Teachers: Min 2 for the group sessions Class hours: Three one-hour classes per week

Meets: All 3 hours are compulsory
ELK Asia Pacific Journals - Special Issue

ISBN: 978-81-930411-1-6

Plenary sessions: One per week

Assessment: Continuous assessment

(90\%) based on two in-class tests plus

weekly quizzes $10 \%$ (best 5 out of 7 to count).

Pre-requisites: None.

Course Text: Required

Students need to purchase the Text book (but the Work-book is optional)

\section{Exercise 5}

\section{Writing Translation}

Writing Translation means making use of a literary work in translation as stimulate for composition - creative assignments developed around plot, characters, setting, theme, and figurative language. There are many forms of writing translation, such as Adding to the Work, Changing the Work, Drama-Inspired Writing and A Letter Addressed to Another Character, etc. This comprises writing imaginary episodes or sequels.

\section{Conclusion}

We live in a world of Translation permeated by different languages at every level from literary books to multilingual working out manuals, from the media and texts to songs and films and all of us translate every day, whether we know it or not. This activity aims to examine major issues related to translation, including its theory and practice, as well as what ideological and ethical concerns translation poses today. We will also explore translation's relationship to issues 
ELK

Asia Pacific Journals

of literature, religion, culture, race and ethnicity, sex and gender in the classroom.

I freely admit an affinity for the translation and I hope students gain from this exercise an understanding that translation is somewhat subjective. They may not be getting the most accurate, word-for-word version in modern English, and focus on different elements. I want them to understand translations are rarely the literary works themselves so much as they are an "imaginative reconstruction" of these works. I also want them to think about the number of decisions translators must face. Through works in translation, students in our mostly poly lingual society are at last becoming acquainted with the multilingual and multicultural world in which they will live and work. Many instructors have expanded their reach to teach texts that originate from across the globe. This paper aims at emphasizing the exercise of literature as a trendy technique for teaching both basic
ELK Asia Pacific Journals - Special Issue

ISBN: 978-81-930411-1-6

language skills (reading, writing, listening and speaking) and language areas (vocabulary, grammar and pronunciation) in our times.

\section{References}

[1] Abrams, M.H. 1970. A Glossary of Literary Term. New York: Rinehart.

[2] Cay Dollerup, Annette Lindegaard, Teaching Translation and Interpreting John Benjamins: 1994.

[3] Carter, R., and Long, M.N. 1991. Teaching literature. Harlow: Longman.

[4] Collie, J., and Slater, S. 1991. Literature in the Language Classroom. (5th ed.). Glasgow: Cambridge University Press.

[5] Hill, Jeniffer. 1994. Using Literature in Language Teaching. London:Macmillan.

[6] Ur, P. A Course in Language Teaching: Practice and Theory. Cambridge: Cambridge University Press, 1996. 